\title{
Ultrasound in Pregnancy: A Cross-sectional Study of Knowledge and Expectations among Pregnant Women in Southwest Turkey
}

\author{
Gebelikte Ultrason: Güneybatı Türkiye'deki Gebe Kadınların Bilgi ve \\ Beklentilerinin Kesitsel Çalışması
}

\author{
Burcu Kasap, Emine Neşe Yeniçeri*, Melike Nur Akın, Eren Akbaba, Mert Küçük, \\ Nilgün Öztürk Turhan, Aylin Sağlam** \\ Muğla Sıtkı Koçman University Faculty of Medicine, Department of Obstetrics and Gynecology, Muğla, Turkey \\ *Muğla Sıtkı Koçman University Faculty of Medicine, Department of Family Medicine, Muğla, Turkey \\ **Tekden Hospital, Clinic of Obstetrics and Gynecology, Istanbul, Turkey
}

\section{Abstract}

\begin{abstract}
Aim: Ultrasound scanning has become universally accepted tool in prenatal care. We sought to evaluate the knowledge and expectations of pregnant women in Turkey towards ultrasound use during pregnancy.
\end{abstract}

Methods: We performed a cross-sectional study of 108 pregnant women in Muğla Sıtkı Koçman University. The subjects completed a questionnaire consisting of three sections: Sociodemographic characteristics, 13-question assessment of knowledge regarding the use of ultrasound during pregnancy, and assessment of expectations. The patients were awarded one point for every correct answer, with total scores categorized into three groups: 0-4 points insufficient, 5-8 points moderately sufficient, and 9-13 points sufficient. Comparisons were performed using the chi-square test.

Results: The mean age of the respondents was 28.6 \pm 4.9 years (1839). Patient knowledge was insufficient in 34 participants (31.4\%), moderately sufficient in 56 participants (51.9\%), and sufficient in 18 participants (16.7\%). Among respondents, 31.5\% believed that structural abnormalities would be detected in at least $40 \%$, while $99 \%$ expected to learn the gender of baby.

Conclusion: The majority of our study population had insufficient to moderately sufficient knowledge regarding the use of ultrasound during pregnancy, with a high degree of misinformation regarding patient expectations. These results suggest a greater need for national education in terms of the diagnostic capabilities and limitations of pregnancy ultrasound.

Keywords: Expectation, knowledge, ultrasound, pregnancy, Turkey
Amaç: Ultrason prenatal bakımda kabul edilmiş uluslararası bir araçtır. Biz de Türkiye'deki gebe kadınların gebelikte ultrason kullanımına yönelik bilgi ve beklentilerini araştırmayı hedefledik.

Yöntemler: Muğla Sıtkı Koçman Üniversitesi'ndeki 108 gebe kadının katılımıyla kesitsel bir çalışma yapıldı. Katılımcıların tamamladığı anket üç bölümden oluşmaktaydl: Sosyodemografik karakteristikler, gebelikte ultrason kullanımılla ilgili bilginin değerlendirildiği 13 soru, beklentilerin değerlendirilmesi. Hastalar her doğru cevap için bir puan alacakları şekilde nihai puanlarılla üç kategoriye ayrıldılar: 0-4 puan yetersiz, 5-8 puan orta düzeyde yeterli ve 9-13 puan yeterli. Gruplar arasındaki karşılaştırmalar ki-kare testi ile değerlendirildi.

Bulgular: Katıımcıların yaş ortalaması 28,6 $\pm 4,9$ yaş (18-39 yaş) idi. Hastaların bilgi düzeyi 34 katılımcıda $(\% 31,4)$ yetersiz, 56 katılımcıda $(\% 51,9)$ orta düzeyde yeterli ve 18 katilımcıda $(\% 16,7)$ yeterli olarak değerlendirildi. Katılımcıların \%31,5'i hastaların en az \%40'ında yapısal anomalilerin tespit edileceğine inanmaktayken, \%99'u bebeğin cinsiyetini öğrenme beklentisi içindeydi.

Sonuç: Çalışmaya dahil olan toplumun çok büyük kısmı gebelikte ultrason kullanımı ile ilgili yetersiz ile orta düzeyde yeterli bilgi düzeyine sahipken hasta beklentileri ile ilgili yüksek düzeyde yanlış bilgilendirme mevcuttu. Bu sonuçlara göre gebelik ultrasonunun tanısal kapasitesi ve kısıtlııkları hakkında ulusal düzeyde daha fazla hasta eğitimine ihtiyaç vardır.

Anahtar Sözcükler: Beklenti, bilgi, ultrason, gebelik, Türkiye
Address for Correspondence/Yazıșma Adresi: Burcu Kasap

Muğla Sıtkı Koçman University Faculty of Medicine, Department of Obstetrics and Gynecology, Muğla, Turkey Phone: +90 2522115156 E-mail: burcuharmandar@gmail.com

Received/Geliş Tarihi: 10 April 2016 Accepted/Kabul Tarihi: 26 April 2016 $201514^{\text {th }}$ Congress of Turkish Gynecology and Obstetrics Association, Antalya, Turkey 'Copyright 2016 by The Medical Bulletin of
Haseki Training and Research Hospital The Medical Bulletin of Haseki published by Galenos Yayınevi. - Telif Hakkı 2016 Haseki Eğitim ve Araştırma Hastanesi Haseki Tıp Bülteni, Galenos Yayınevi tarafından basıımıştır. 


\section{Introduction}

Ultrasound scans have become universally accepted tools in prenatal care throughout much of the world (1), used for both screening and diagnosis (2). As a screening tool, ultrasound is used for low-risk patients to confirm gestational age, multiple pregnancy, and fetal abnormalities $(3,4)$. Congenital abnormalities are most commonly seen in patients with no known risk factors. As detection of most malformations becomes possible in the late first trimester, the optimum time for an anomaly scan is 18-20 weeks (5). While the vast majority of pregnant women react positively to the use of ultrasound during pregnancy, many women report feelings of anxiety regarding the possibility of bad news (1), particularly those from lower sociodemographic groups (6). To overcome such difficulties, patients should be informed as to who is performing the scan, its purpose, and what is occurring during the procedure. Adherence to these basic guidelines has been shown to positively affect both the knowledge level and expectations of pregnant women regarding the use of ultrasound. Greater recognition of differences in patient knowledge, along with both realistic and unrealistic expectations within the pregnant population, is important for healthcare workers as a means of limiting negative consequences associated with ultrasound examinations. While studies examining the knowledge and expectations of pregnant women regarding the use of ultrasound during pregnancy have been conducted in Denmark (7), Ireland (8), Sweden (9), United Kingdom (10), and China (11), these studies cannot be adapted to the Turkish population due to significant sociodemographic discrepancies. For this reason, we devised a cross-sectional survey using self-administered questionnaires to evaluate the knowledge and expectations of Turkish pregnant women regarding the use of ultrasound during pregnancy.

\section{Methods}

We performed a cross-sectional survey of pregnant women seen in Muğla Sıtkı Koçman University prenatal clinic in Muğla, Turkey. Ethical approval for this study was obtained from the Health Sciences Ethics Committee of Muğla Sıtkı Koçman University and therefore the study has been performed in accordance with the ethical standards laid down in the 1964 Declaration of Helsinki. All participants signed written informed consents. The questionnaire was based upon those used in similar studies from Denmark (12) and China (11). The questionnaire was initially validated by offering a pilot questionnaire form among 20 pregnant women to determine whether the questions were written at an appropriate understanding level of the participants. Five gynecologists were asked to criticize the content of the questionnaire. The questionnaire forms were sent to a total of 122 responders who had not undergone first trimester prenatal screening tests, while 14 questionnaire forms were not completed adequately. The questionnaire consisted of three sections. The first part evaluated the sociodemographic characteristics of the study participants, including maternal age, gestational age, education levels of both the pregnant woman and her partner, monthly family income, occupational status, previous visits to stateemployed or private obstetricians, previous visits to a family physician, gravidity and parity numbers, and awareness of the term perinatology. The first section also evaluated the source of knowledge about using ultrasound in pregnancy. The second section consisted of 13 questions evaluating the level of patient knowledge regarding the use of ultrasound during pregnancy. The contents focused on the goals of pregnancy ultrasound, the detection rate for abnormalities, the limitations of ultrasound, the gestational period during which anomaly scans are performed, and the safety of ultrasound examinations. The patients were awarded one point for every correct answer, with total scores categorized into three groups: 0-4 points was classified as insufficient, 5-8 points was classified as moderately sufficient, and 9-13 points was deemed sufficient. The third part of the questionnaire examined expectations of the pregnant women prior to pregnancy ultrasound. Here, questions focused on the detection rate of pregnancy ultrasound for anomalies, the number of scans performed over the course of pregnancy, the identity of the sonographer (obstetrician/radiologist/ family physician), and desire to learn the gender of the baby. Variables were categorized according to the data of the Women's Health Project in Turkey (13). All data were recorded and analyzed using the SPSS for Windows software (v. 20.0; SPSS Inc., Chicago, IL, USA). Simple descriptive statistics were used for the sociodemographic data. Categorical variables were compared using the chisquare test. $P$ values of less than 0.05 were considered statistically significant.

\section{Results}

A full list of patient demographic data can be found in Table 1. The mean age of the respondents was $28.6 \pm 4.9$ years (range: 18-39 years). The mean gestational age was 11.21 \pm 2.65 weeks (range: 4-14 weeks). Among pregnant women and their partners, $50.9 \%$ and $67.6 \%$, respectively, reported an educational level higher than high school diploma. In total, 53\% of the participants had a monthly household income higher than the minimum wage ( $\$ 350$ USD); $47 \%$ of participants lived in the city. Among respondents, $62 \%$ were unemployed. The rate of the previous visits to state-employed obstetricians, private obstetricians, and family physicians was 63\%, 38.9\% and 
$51.8 \%$, respectively. In terms of prior pregnancies, $37.9 \%$ were nulliparous; the remaining $62.1 \%$ reported at least one prior pregnancy, of which $75.9 \%$ had more than two previous pregnancies. Only $12.9 \%$ of pregnant women were aware of the term perinatology. For part two of the survey, 34 participants (31.4\%) were categorized as having an insufficient level of knowledge (0-4 correct answers), $56(51.9 \%)$ were categorized as having a moderately sufficient level of knowledge (5-8 correct answers), and $18(16.7 \%)$ were categorized as having a sufficient level of knowledge (9-13 correct answers) (Table 2).

The relationship between knowledge about pregnancy ultrasound and sociodemographic characteristics is shown in Table 3. Univariate analysis showed that the level of knowledge about pregnancy ultrasound was significantly correlated with age $(p=0.017)$, education level $(p=0.009)$, place of residency $(p=0.039)$, previous visits to private obstetricians and family physicians $(p=0.0025$ and $p \leq 0.001$, respectively), and parity ( $p \leq 0.001)$. It was found that the level of knowledge about pregnancy ultrasound was not associated with the level of the partner's education, monthly family income, occupational status, previous visits to state-employed obstetricians, or gravidity. Doctors, healthcare staff, and brochures were the most commonly cited sources of ultrasound-related information, while television and radio were the least common (Figure 1). Within these data, a statistically significant correlation was observed between women who had previously visited a private obstetrician and those citing doctors, healthcare staff, and brochures as their primary source of information, while women who had not previously visited a private obstetrician were more likely to cite television and radio

\begin{tabular}{|c|c|c|}
\hline & $\mathrm{n}$ & $\%$ \\
\hline $\begin{array}{l}\text { Age (years) } \\
<30 \\
\geq 30\end{array}$ & $\begin{array}{l}61 \\
47 \\
\end{array}$ & $\begin{array}{r}56.5 \\
43.5 \\
\end{array}$ \\
\hline $\begin{array}{l}\text { Education level of pregnant women } \\
<\text { High school } \\
\geq \text { High school }\end{array}$ & $\begin{array}{l}53 \\
55 \\
\end{array}$ & $\begin{array}{l}49.1 \\
50.9 \\
\end{array}$ \\
\hline $\begin{array}{l}\text { Education level of partner } \\
<\text { High school } \\
\geq \text { High school }\end{array}$ & $\begin{array}{l}35 \\
73\end{array}$ & $\begin{array}{l}32.4 \\
67.6\end{array}$ \\
\hline $\begin{array}{l}\text { Family income } \\
\leq \cup S D 350 \\
>\text { USD } 350\end{array}$ & $\begin{array}{l}51 \\
57 \\
\end{array}$ & $\begin{array}{l}47 \\
53 \\
\end{array}$ \\
\hline $\begin{array}{l}\text { Place of residency } \\
\text { Village, county } \\
\text { City }\end{array}$ & $\begin{array}{l}57 \\
51\end{array}$ & $\begin{array}{l}53 \\
47 \\
\end{array}$ \\
\hline $\begin{array}{l}\text { Occupation } \\
\text { Employed } \\
\text { Unemployed }\end{array}$ & $\begin{array}{l}41 \\
67 \\
\end{array}$ & $\begin{array}{l}38 \\
62 \\
\end{array}$ \\
\hline $\begin{array}{l}\text { Previous visits to state-employed obstetri } \\
\text { Yes } \\
\text { No }\end{array}$ & $\begin{array}{l}68 \\
40\end{array}$ & $\begin{array}{l}63 \\
37\end{array}$ \\
\hline $\begin{array}{l}\text { Previous visits to private obstetrician } \\
\text { Yes } \\
\text { No }\end{array}$ & $\begin{array}{l}42 \\
66\end{array}$ & $\begin{array}{l}38.9 \\
61.1\end{array}$ \\
\hline $\begin{array}{l}\text { Previous visits to family physician } \\
\text { Yes } \\
\text { No }\end{array}$ & $\begin{array}{l}56 \\
52\end{array}$ & $\begin{array}{l}51.8 \\
48.2\end{array}$ \\
\hline $\begin{array}{l}\text { Gravidity } \\
1 \\
\geq 2\end{array}$ & $\begin{array}{l}23 \\
85 \\
\end{array}$ & $\begin{array}{l}24.1 \\
75.9 \\
\end{array}$ \\
\hline $\begin{array}{l}\text { Parity } \\
\text { Nulliparous } \\
\text { Multiparous }\end{array}$ & $\begin{array}{l}41 \\
67\end{array}$ & $\begin{array}{l}37.9 \\
62.1\end{array}$ \\
\hline
\end{tabular}

\begin{tabular}{|l|l|l|l|l|}
\hline \multicolumn{2}{|c|}{ Table 2. Answers of pregnant women to questions regarding knowledge on ultrasound (n=108) } \\
\hline & Questions & $\begin{array}{l}\text { Correct answer } \\
\text { n (\%) }\end{array}$ & $\begin{array}{l}\text { Wrong answer } \\
\text { n (\%) }\end{array}$ & $\begin{array}{l}\text { Don't know } \\
\text { n (\%) }\end{array}$ \\
\hline 1 & Can ultrasound evaluate fetal growth? & $84(77.8)$ & $17(15.7)$ & $7(6.5)$ \\
\hline 2 & Can ultrasound evaluate fetal morphology? & $54(50)$ & $44(40.7)$ & $10(9.3)$ \\
\hline 3 & Can ultrasound evaluate amniotic fluid volume? & $63(58.3)$ & $29(26.9)$ & $16(14.8)$ \\
\hline 4 & Can ultrasound evaluate the placental site? & $60(55.6)$ & $30(27.8)$ & $18(16.7)$ \\
\hline 5 & $\begin{array}{l}\text { Can ultrasound diagnose chromosomal or genetic abnormalities (e.g. } \\
\text { Down syndrome, thalassemia)? }\end{array}$ & $32(29.6)$ & $10(9.3)$ & $66(61.1)$ \\
\hline 6 & $\begin{array}{l}\text { Is any specific preparation needed prior to an ultrasound examination (e.g. } \\
\text { fasting)? }\end{array}$ & $59(54.6)$ & $9(8.3)$ & $40(37)$ \\
\hline 7 & Can ultrasound evaluate the level of fetal intelligence? & $56(51.9)$ & $17(15.7)$ & $35(32.4)$ \\
\hline 8 & When is the routine morphology scan usually performed? & $18(16.7)$ & $6(5.6)$ & $84(77.8)$ \\
\hline 9 & Is morphology ultrasound obligatory? & $76(70.4)$ & $21(19.4)$ & $11(10.2)$ \\
\hline 10 & Is ultrasoundsafe to fetuses? & $47(43.5)$ & $9(8.3)$ & $52(48.1)$ \\
\hline 11 & Can ultrasound diagnose all structural abnormalities? & $14(13)$ & $20(18.5)$ & $74(68.5)$ \\
\hline 12 & Is transvaginal ultrasound safe for both fetus and mother? & $21(19.4)$ & $22(20.4)$ & $65(60.2)$ \\
\hline 13 & Which pregnant women are recommended to have an anomaly scan? & $68(63)$ & $20(18.5)$ & $20(18.5)$ \\
\hline
\end{tabular}


as their primary source of information $(p \leq 0.001)$. In terms of patient expectations, $10 \%$ of participants believed that ultrasound would detect structural abnormalities in $>90 \%$ of individuals (Figure 2). Among all respondents, $31.5 \%$ of women believed that structural abnormalities would be detected in $>40 \%$ of patients (data not shown),

\begin{tabular}{|c|c|c|c|c|}
\hline \multicolumn{5}{|c|}{ Knowledge level of the pregnant women about ultrasound } \\
\hline & $\begin{array}{l}\text { Insufficient } \\
(n=34)\end{array}$ & $\begin{array}{l}\text { Moderately } \\
\text { sufficient } \\
(n=56)\end{array}$ & $\begin{array}{l}\text { Sufficient } \\
(\mathrm{n}=18)\end{array}$ & $\mathrm{p}$ \\
\hline $\begin{array}{l}\text { Age (years) } \\
<30 \\
\geq 30\end{array}$ & $\begin{array}{l}26 \\
8 \\
\end{array}$ & $\begin{array}{l}27 \\
29 \\
\end{array}$ & $\begin{array}{l}8 \\
10 \\
\end{array}$ & ${ }^{\star} 0.017$ \\
\hline $\begin{array}{l}\text { Education level of } \\
\text { pregnant woman } \\
<\text { High school } \\
\geq \text { High school }\end{array}$ & $\begin{array}{l}24 \\
10\end{array}$ & $\begin{array}{l}23 \\
33\end{array}$ & $\begin{array}{l}6 \\
12\end{array}$ & *0.009 \\
\hline $\begin{array}{l}\text { Education level of } \\
\text { partner } \\
<\text { High school } \\
\geq \text { High school }\end{array}$ & $\begin{array}{l}15 \\
19 \\
\end{array}$ & $\begin{array}{l}15 \\
41 \\
\end{array}$ & $\begin{array}{l}5 \\
13 \\
\end{array}$ & 0.211 \\
\hline $\begin{array}{l}\text { Monthly family } \\
\text { income } \\
\text { SUSD } 350 \\
\text { >USD } 350\end{array}$ & $\begin{array}{l}20 \\
14 \\
\end{array}$ & $\begin{array}{l}23 \\
33 \\
\end{array}$ & $\begin{array}{l}8 \\
10 \\
\end{array}$ & 0.254 \\
\hline $\begin{array}{l}\text { Place of residency } \\
\text { Village, county } \\
\text { City }\end{array}$ & $\begin{array}{l}22 \\
12 \\
\end{array}$ & $\begin{array}{l}30 \\
26 \\
\end{array}$ & $\begin{array}{l}5 \\
13 \\
\end{array}$ & *0.039 \\
\hline $\begin{array}{l}\text { Occupation } \\
\text { Employed } \\
\text { Unemployed } \\
\text { (housewife) }\end{array}$ & $\begin{array}{l}11 \\
23\end{array}$ & $\begin{array}{l}21 \\
35\end{array}$ & $\begin{array}{l}9 \\
9\end{array}$ & 0.457 \\
\hline $\begin{array}{l}\text { Previous visits to } \\
\text { public hospital } \\
\text { obstetrician } \\
\text { Yes } \\
\text { No }\end{array}$ & $\begin{array}{l}24 \\
10 \\
\end{array}$ & $\begin{array}{l}39 \\
17 \\
\end{array}$ & $\begin{array}{l}5 \\
13 \\
\end{array}$ & 0.978 \\
\hline $\begin{array}{l}\text { Previous visits to } \\
\text { private obstetrician } \\
\text { Yes } \\
\text { No }\end{array}$ & $\begin{array}{l}10 \\
24\end{array}$ & $\begin{array}{l}20 \\
36\end{array}$ & $\begin{array}{l}12 \\
6\end{array}$ & *0.025 \\
\hline $\begin{array}{l}\text { Previous visits to } \\
\text { family physician } \\
\text { Yes } \\
\text { No }\end{array}$ & $\begin{array}{l}5 \\
29\end{array}$ & $\begin{array}{l}39 \\
17\end{array}$ & $\begin{array}{l}12 \\
6\end{array}$ & ${ }^{*} 0.000$ \\
\hline $\begin{array}{l}\text { Gravidity } \\
1 \\
\geq 2\end{array}$ & $\begin{array}{l}9 \\
25\end{array}$ & $\begin{array}{l}9 \\
47\end{array}$ & $\begin{array}{l}5 \\
13\end{array}$ & 0.386 \\
\hline $\begin{array}{l}\text { Parity } \\
\text { Nulliparous } \\
\text { Multiparous }\end{array}$ & $\begin{array}{l}24 \\
10 \\
\end{array}$ & $\begin{array}{l}11 \\
45 \\
\end{array}$ & $\begin{array}{l}6 \\
12 \\
\end{array}$ & ${ }^{*} 0.000$ \\
\hline $\begin{array}{l}\text { Being aware of the } \\
\text { term perinatology } \\
\text { Yes } \\
\text { No }\end{array}$ & $\begin{array}{l}4 \\
30\end{array}$ & $\begin{array}{l}5 \\
51\end{array}$ & $\begin{array}{l}5 \\
13\end{array}$ & 0.113 \\
\hline
\end{tabular}

although nearly $80 \%$ of participants admitted that they did not know the detection rate. In total, $80 \%$ of patients expected scanning to be performed at every visit (Figure 3), with $99 \%$ assuming that the healthcare provider performing the scan was an obstetrician. More than $99 \%$ of respondents expected to be able to learn the gender of their baby.

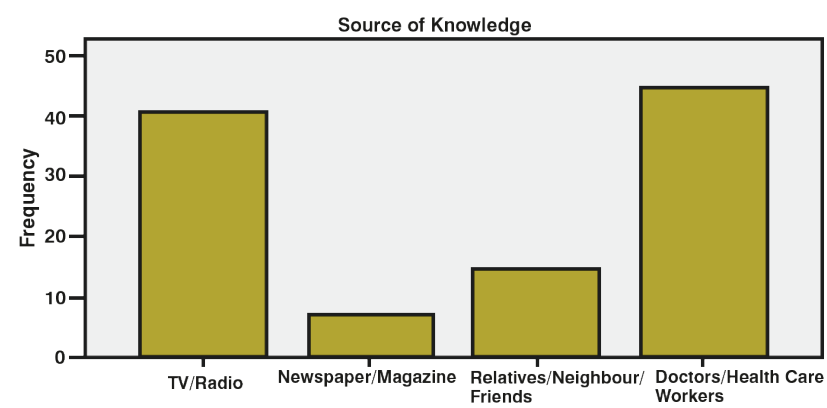

Figure 1. Source of information

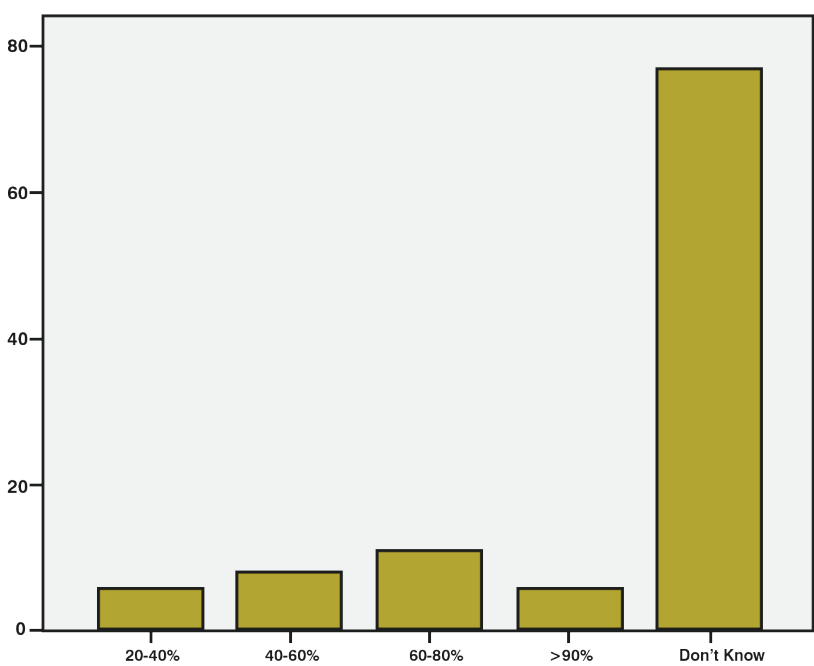

Figure 2. Detection rate expectation

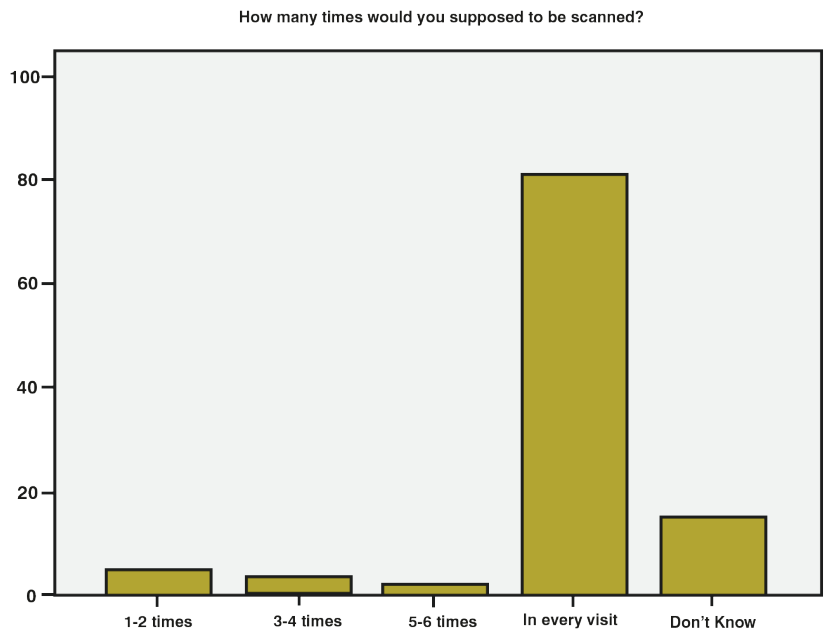

Figure 3. Number of scans expectation 


\section{Discussion}

This cross-sectional study was conducted at a university hospital in Muğla, a city in Southwestern Turkey with a population of 890.000 , to evaluate the knowledge levels and expectations of pregnant women regarding the use of ultrasound during pregnancy. Our results revealed a considerable lack of knowledge regarding the use of ultrasound during pregnancy, despite considerable interest in the procedure. The present study demonstrated that the main sources of information for pregnancy ultrasound among our study population were doctors, healthcare staff, and brochures. This observation is in marked contrast with a previous study which found that health professionals provide little information to women during their pregnancy (9). A similar study by Chan et al. (11) reported that the major sources of ultrasound knowledge for nulliparous women were friends, relatives, and private doctors, whereas prior experience and healthcare providers were the primary sources of knowledge for multiparous women. Here, we observed a significant discrepancy in patient knowledge based upon healthcare providers, with those who had previously visited private obstetricians exhibiting greater knowledge of ultrasound use during pregnancy than those who had visited stateemployed obstetricians. This difference is likely due to the lower number of patients examined at private prenatal clinics, which generally allows for longer examination times, and better patient education. This observation suggests a need for longer examination times in public hospitals, a need to develop efficient educational tools to convey information in busy settings to enable better patient education. In another perspective, physicians who work for public health should be motivated to instruct appropriate skills for patient education. The highest level of knowledge regarding the use of ultrasound during pregnancy was seen in multiparous women, as well as in those $>30$ years of age, likely the result of experience gained during previous pregnancies. A strong association was also seen between ultrasound knowledge and patient educational level, as expected. Women living in the city had higher levels of knowledge relative to those living in more rural areas, consistent with the findings of a similar study from China (11).

The overall correct answer rate for fetal growth, amniotic fluid volume, and the placental site were satisfactory, however, $40.7 \%$ of participants did not know that ultrasound could be used to assess fetal morphology. While $61.1 \%$ of respondents indicated that they did not know if ultrasound could be used to diagnose chromosomal or genetic abnormalities (e.g. Down syndrome or thalassemia), only $29.6 \%$ were able to answer correctly. Similarly, $68.5 \%$ of respondents did not know whether or not ultrasound could be used to diagnose any kind of abnormality. According to the Eurofetus study, the largest prospective study ever performed, the overall fetal detection rate for anomalous fetuses was $61.4 \%(14)$. In another study, the detection rate for significant abnormalities was found to be $55 \%$ (15). In our study, the majority of the participants did not know the detection rate of ultrasound examinations and only $13 \%$ were correct in their estimation of the detection rate of fetal abnormalities. The primary objective of the 18-23-week anomaly scan is to reassure the patient that the fetus has no pronounced structural abnormality, a goal which should be clear to all patients prior to performing the scan (16). However, in our study, only $22.2 \%$ of respondents were able to correctly identify the interval for the anomaly scan. These results suggest a need for more patient education regarding the timing and purpose of the anomaly scan, ideally at the beginning of prenatal care. The expected anomaly rate in our study was very high, with $31.5 \%$ of the pregnant women reporting an expected anomaly rate $\geq 40 \%$, albeit lower than that of Chan et al. (11) who reported that over $70 \%$ of their study population believed the overall detection rate of ultrasound to be $>40 \%$. These observations are broadly consistent with that of a previous report on women's perception and knowledge of the second trimester, where only $8 \%$ of respondents knew the detection rate of the anomaly scan (10). In the present study, $8 \%$ of respondents anticipated an anomaly detection rate $>90 \%$ from the ultrasound examination. Since these unrealistic over-expectations may lead to both medical and legal complications, greater efforts must be made to correct these misconceptions. Overall knowledge levels regarding the need for specific preparation prior to ultrasound were satisfactory. Transabdominal ultrasonography scanning with a full bladder might increase the quality of images in the first trimester, although this is generally not necessary at advanced gestational ages. Also, fasting is not necessary for obstetric examinations. This knowledge may reduce the number of patients waiting in a state of hunger for several hours, which on occasion can lead to both dizziness and fainting. In terms of expectations regarding ultrasound safety, $43.5 \%$ of participants thought that ultrasound was safe; while $8.3 \%$ worried that ultrasound may be harmful to the fetus. These results are considerably lower than those of Eurenius et al. (9) and Chan et al. (11) studies in which $99 \%$ and $83.3 \%$ of pregnant women, respectively, believed ultrasound to be safe. Despite its widespread use, the safety of ultrasound is not without debate. Ultrasound can cause biological effects through heating, cavitation, and micro-streaming, though it has been shown that ultrasound is safe for the developing embryo 
at temperatures up to $1^{\circ} \mathrm{C}(17)$. Therefore, pregnant women should be reassured that ultrasound scanning is safe when examination times are not prolonged and the lowest output settings are used. Transvaginal ultrasound is more uncomfortable than abdominal ultrasound and, when performing vaginal ultrasound, the application of gentle pressure to the uterus and transducer rotation in combination with manual abdominal pressure is necessary. For this reason, only $19.4 \%$ of participants thought that transvaginal ultrasound was safe, compared to $20.4 \%$ who thought that the procedure may be harmful for either the mother or the fetus. In a study conducted by LevmoreTamir et al. (18) it was demonstrated that a transvaginal ultrasound anomaly scan conducted in the early second trimester of pregnancy is safe for the fetus, and does not cause adverse perinatal outcomes, such as placental abruption or cord entanglement when compared to an abdominal non-vaginal ultrasound anomaly scan.

In low-risk pregnancies with a background prevalence of $2 \%$ fetal abnormalities, ultrasound screening has proven effective in the diagnosis of fetal abnormalities. According to the Routine Antenatal Diagnostic Imaging with Ultrasound Study, only 39\% of the prenatal population constituted a truly low-risk group $(19,20)$. In our study, $63 \%$ of the participants knew that anomaly scans are recommended in all patients, not just for highrisk pregnancies, while $70 \%$ of participants knew that the second trimester anomaly scan is not obligatory, and they have the right to refuse an ultrasound examination. This result is similar to that of a Chinese study in which $65 \%$ of participants knew that ultrasound was not compulsory (11). Beyond basic diagnostic uses, ultrasound imaging may also have a bonding effect between the mother, partner, and fetus (21), although scans are not necessarily performed at every visit. In Denmark, since the introduction of the Danish National Board of Health guidelines in 2004, all Danish pregnant women have been offered two ultrasound scans, one at 11-14 weeks as a risk evaluation for Down syndrome, and one at 1820 weeks as a fetal anomaly scan (22). Expert opinion asserts that, when there are no specific indications for a first trimester examination, 18-20 weeks gestation is the appropriate time for a single ultrasound examination. All patients should be informed of the advantages and disadvantages of ultrasonography (23). According to the prenatal care guidelines of the Turkish Ministry of Health, five or six prenatal examinations are recommended, although the number of recommended ultrasound scans is not addressed (24). In our study, $80 \%$ of participants expected to be scanned at every prenatal examination, an unrealistic expectation given the added time and expense associated with ultrasound scans.
Ultrasounds are routinely performed by three different groups of medical professionals: Sonographers, radiologists, and obstetricians. A sonographer is a medical specialist who uses sound waves to obtain images, while a radiologist is a doctor who specializes in scientific imaging. In Denmark, sonographers are often midwives or nurses certified by the Fetal Medicine Foundation to perform routine ultrasound scans, with doctors only consulted in cases of pathological conditions (22). In our study, there was an almost universal expectation among the pregnant population (99\%) to be scanned by an obstetrician rather than a radiologist or family physician. This is likely due to the lack of formal training available for family practitioners in pregnancy ultrasound, as well as the unwillingness of pregnant women to schedule appointments with a radiologist, a process that may keep patients waiting for months. Despite a lack of formal training for family practitioners, the level of ultrasound knowledge was positively associated with prior visits to both private prenatal clinics and family physicians. In contrast, previous visits to public prenatal clinics were not correlated with an increase in the level of knowledge regarding ultrasound examinations. As the physical and mental preparation of women for pregnancy should begin at their primary care facility, expanded training programs for family physicians may enable better prenatal care, reducing the burden on obstetricians. Modern ultrasound machines allow us to readily identify the gender of the fetus. The detection rate of fetal gender at 16 weeks ranges from $64-97 \%$, with an accuracy of 93-99\% (25). In our study, $99 \%$ of women expected to learn the gender of their fetus during their ultrasound examination. In a study of 472 pregnant women by Harrington et al. (26) $74.7 \%$ wanted to know the gender of the baby. Given a standard 20 minutes for each anomaly scan, without any additional time to detect the gender of the fetus, $96.7 \%$ of the scans produced a correct diagnosis for gender (26). The highest rate of patients wanting to know the gender of their fetus was reported by Chan et al. (11) who observed that $>90 \%$ of their population wanted to know the gender of the baby, an outcome likely associated with traditional Chinese culture, and the preference for male offspring (11). In contrast, these levels were considerably lower among Caucasian populations $(7,8)$. While it is generally reasonable to provide this information to prospective parents, it is important for patients to be aware of both the limitations and misdiagnosis rates associated with ultrasound detection of gender. This study had several limitations. One of the main limitations was that the pregnant women were surveyed regarding their knowledge of ultrasound in general. This level of knowledge did not address the use of separate routine and anomaly scans. The study also could not ascertain if women were aware of specific fetal 
abnormalities. Conducting the study at a university prenatal clinic, which serves a predominantly high-income, welleducated population, is also likely to have influenced our results.

\section{Conclusion}

The majority of our study population was deemed to have insufficient to moderately sufficient knowledge regarding the use of ultrasound during pregnancy, with a high degree of misinformation regarding patient expectations. These observations suggest a need for detailed information packs and informed consent forms as a means of better-educating patients about the use and outcomes associated with pregnancy ultrasound. While the results presented here do show important differences relative to previous studies, it is important to assess each pregnant woman's knowledge and expectations relative to the social values of her own country. Informed consent forms should be reviewed in detail with each woman before the ultrasound examination, with an emphasis on the goals and limitations of the procedure, to overcome unrealistic expectations. Additional training of ultrasound examination staff may be necessary to achieve these goals.

\section{Acknowledgements}

We would like to thank the pregnant women who participated in this study, and to the staff in the Muğla Sıtkı Koçman University Training and Research Hospital Antenatal Clinics for their efforts in data collection during busy routine works.

\section{Ethics}

Ethics Committee Approval: Ethical approval for this study was obtained from the Health Sciences Ethics Committee of Muğla Sıtkı Koçman University. Informed Consent: It was taken.

Peer-review: Internally peer-reviewed.

\section{Authorship Contributions}

Concept: Burcu Kasap, Emine Neşe Yeniçeri, Nilgün Öztürk Turhan. Design: Mert Küçük. Data Collection or Processing: Burcu Kasap, Melike Nur Akın, Eren Akbaba. Analysis or Interpretation: Burcu Kasap, Emine Neşe Yeniçeri. Literature Search: Burcu Kasap, Aylin Sağlam. Writing: Burcu Kasap.

Conflict of Interest: No conflict of interest was declared by the authors.

Financial Disclosure: The authors declared that this study received no financial support.

\section{References}

1. Garcia J, Bricker L, Henderson J, et al. Women's views of pregnancy ultrasound: a systematic review. Birth 2002;29:22550.

2. Seeds JW. The routine or screening obstetrical ultrasound examination. Clin Obstet Gynecol 1996;39:814-30.
3. Tunon K, Eik-Nes SH, Grottum P. The impact of fetal, maternal and external factors on prediction of the day of delivery by the use of ultrasound. Ultrasound Obstet Gynecol 1998;11:99-103.

4. Bricker L, Garcia J, Henderson J, et al. Ultrasound screening in pregnancy: a systematic review of the clinical effectiveness, cost-effectiveness and women's views. Health Technol Assess 2000;4:1-193.

5. Rayburn WF, Jolley JA, Simpson LL. Advances in ultrasound imaging for congenital malformations during early gestation. Birth Defects Res A Clin Mol Teratol 2015;103:260-8.

6. Rice PL, Naksook C. Pregnancy and technology: Thai women's perceptions and experience of prenatal testing. Health Care Women Int 1999;20:259-78.

7. Larsen $T$, Nguyen TH, Munk M, et al. Ultrasound screening in the 2nd trimester. The pregnant woman's background knowledge, expectations, experiences and acceptances. Ultrasound Obstet Gynecol 2000;15:383-6.

8. Lalor JG, Devane D. Information, knowledge and expectations of the routine ultrasound scan. Midwifery 2007;23:13-22.

9. Eurenius K, Axelsson O, Gallstedt-Fransson I, et al. Perception of information, expectations and experiences among women and their partners attending a second-trimester routine ultrasound scan. Ultrasound Obstet Gynecol 1997;9:86-90.

10. Basama FM, Leonard B, Leighton M. Audit: women's perception and knowledge of the 20 weeks anomaly scan. J Obstet Gynaecol 2004;24:44-6.

11. Chan LW, Chan OK, Chau MC, et al. Expectation and knowledge of pregnant women undergoing first and second trimester ultrasound examination in a Chinese population. Prenat Diagn 2008;28:739-44.

12. Larsen $T$, Nguyen TH, Munk $M$, et al. Ultrasound screening in the 2nd trimester. The pregnant woman's background knowledge, expectations, experiences and acceptances. Ultrasound Obstet Gynecol 2000;15:383-6.

13. Turkey Women Health project, General Directorate of Health Research, Ministry of health, http://www.sagem.gov.tr/ kadin_sagligi_arastirmasi_28_04_2014.pdf.

14. Grandjean H, Larroque D, Levi S. Sensitivity of routine ultrasound screening of pregnancies in the Eurofetus database. The Eurofetus Team. Ann N Y Acad Sci 1998;847:118-24.

15. Boyd PA, Chamberlain P, Hicks NR. 6-year experience of prenatal diagnosis in an unselected population in Oxford, UK. Lancet 1998;352:1577-81.

16. RCOG Working Party Routine Ultrasound Screening in Pregnancy: Standards and Training. London, RCOG Press, 2000.

17. National Council on radiation protection and measurements (NCRP). Exposure criteria for medical diagnostic ultrasound: I. Criteria based on thermal mechanisms. (Report No. 113). Bethesda, MD: National Council on Radiation Protection and Measurements; 1992.

18. Levmore-Tamir M, Tsafrir A, Boldes R, et al. Early second trimester transvaginal ultrasound anomaly scan does not cause adverse perinatal outcome. Early Hum Dev 2015;91:239-42. 
19. Ewigman BG, Crane JP, Frigoletto FD, et al. Effect of prenatal ultrasound screening on perinatal outcome. RADIUS Study Group. N Engl J Med 1993;329:821-7.

20. Crane JP, LeFevre ML, Winborn RC, et al. A randomized trial of prenatal ultrasonographic screening: impact on the detection, management, and outcome of anomalous fetuses. The RADIUS Study Group. Am J Obstet Gynecol 1994;171:392-9.

21. Van der Zalm JE, Byrne PJ. Seeing baby: women's experience of prenatal ultrasound examination and unexpected fetal diagnosis. J Perinatol 2006;26:403-8.

22. Thorup TJ, Zingenberg $\mathrm{H}$. Use of 'non-medical' ultrasound imaging before mid-pregnancy in Copenhagen. Acta Obstet Gynecol Scand 2015;94:102-5.
23. American College of O, Gynecologists. ACOG Practice Bulletin No. 101: Ultrasonography in pregnancy. Obstet Gynecol 2009;113:451-61.

24. Turkish Republic Ministry of Health association of Public Health. Antenatal Care Management Guideline. Department of Woman and Reproduction Health, Publication No:924, Ankara,2014.

25. Natsuyama E. Sonographic determination of fetal sex from twelve weeks of gestation. Am J Obstet Gynecol 1984; 149:748-57.

26. Harrington K, Armstrong V, Freeman J, et al. Fetal sexing by ultrasound in the second trimester: maternal preference and professional ability. Ultrasound Obstet Gynecol 1996;8:318-21. 